\title{
Research on the Reform of Professional Practice Course Evaluation Model for Comprehensive Ability
}

\author{
Shouhua Chen ${ }^{\mathrm{a}}$, Weiwei Liu ${ }^{\mathrm{b}}$ and Bo Zhang ${ }^{\mathrm{c}}$
}

Department of technical support engineering, The Academy of Armored Forces Engineering,

Beijing 100072, China;

abeijingcsh@tom.com, bjanicpaper@126.com, 'czb5616@163.com

Keywords: comprehensive ability; professional practice course; evaluation model; reform.

Abstract. For the problems of insufficient of professional practice courses traditional examination mode in capability evaluation and weak directivity, according with the actual typical curriculum design courses in our unit, the present situation of the curriculum assessment model is expounded, the existing problems is analyzed, the suggestions of professional practice course examination mode reform program are proposed. The theory with the actual engineering application to the student, teamwork and innovation practice comprehensive ability evaluation is researched, in order to provide feedback to improve the teaching quality.

\section{Introduction}

In the process of personnel training, teachers impart and teach knowledge to students who acquire knowledge and skills. The students can effectively grasp and flexibly use the curriculum knowledge elations to the level of training quality personnel. In the course of teaching, curriculum evaluation is the final part, and also the inspection method of personnel training quality. Scientific evaluation model will stimulate the enthusiasm of the students. The teachers carry out the reform of teaching mode to promote the role of reverse, help students mastering the knowledge and improve their ability $[1,2]$.

Compared with the professional theory course, professional practice course of course design class pays more attention to the cultivation of practice ability ${ }^{[3,4]}$. These courses not only make students deepen grasp of the relevant theoretical knowledge, but also strengthen the knowledge to ability of transformation, train the ability of students to integrate theory with practice of engineering application, innovative practice ability, pioneering ability and the team cooperation spirit. At present the courses examination failed to fully cover the cultivation of students' comprehensive ability, also have no positive feedback effect on teaching, therefore, to carry out the assessment model based on the comprehensive ability of professional practice course is very urgent and meaningful research and reform.

\section{Analysis of the situation of professional practice courses examination mode}

\subsection{Basic situation}

As an example "systems engineering course design" course, the current courses are adopted process inspection and final inspection with the combination of comprehensive evaluation. Process assessment is mainly considered classroom performance, homework and the practice report; course final inspection is in the form of "reply". The process of appraisal result accounts for $30 \%$ of the total grade, including class performance and homework performance at ordinary times; course final assessment result accounts for $70 \%$ of the total grade, including curriculum design report and reply. This assessment method to a certain extent meets the needs of curriculum assessment. But with the development of students' comprehensive ability training requirements, the current evaluation mode of students' comprehensive abilities directivity is not strong, weak operability. The problem of subjectivity is gradually highlighted. 


\subsection{The existing problems}

As professional practice courses there is much different to the general theory course in training students' engineering application ability, innovation, practical ability, pioneering ability and other comprehensive ability, teaching ways and so on. Examination is more difficult and more often used in the practice of grouping operations, so the assessment model is often not very objective evaluation of each student's learning situation. Generally speaking, there are some problems in the examination mode of professional practice course in the following aspects.

(1) Process assessment is strongly subjective and not rigorous. Especially for the usual performance evaluation, due to the lack of specific evaluation criteria, the teachers will often be based on the impression of the students to mark. At the same time, because course is only a small part of the class, is a theoretical model and most of the time is the student's own homework, the teacher is also very difficult to give a specific conclusion just according to the answer questions and notes.

(2) There is too much emphasis on teamwork but overall consideration of the contribution rate of the group of students in the curriculum design is not enough. This problem is reflected in the curriculum practice report writing. In the actual operation process, some members' time and energy is much greater than other individual members, but because it is in accordance with the group score, ultimately the results of their scores are the same. So the results failed to reflect the individual contribution, which affected the enthusiasm of some members of the team.

(3) Overgeneralization situation prone to reply. Examinations in the form of reply, students are usually randomly selected to reply, which leads to the score of reply are a greater randomness. If the students have a strong ability to express and the early participation in more work, the respondent will be better; on the contrary, the situation is not ideal. Also because it is based on group score, resulting in the group of other members of the reply performance by the respondent influence is too large.

\section{The reform plan of professional practice courses examination mode}

To the above main problems existed in the current professional practice examination mode in the course of status can be resolved, from the angle of improving students' comprehensive ability training and of requirements in accordance with the professional practice course of rules and characteristics as well as the talent training goal, reform plan of the examination mode is put forward.

\subsection{Detailed evaluation index system}

Based on the original assessment scheme, the usual evaluation grades and test scores are refined. Classroom performance is divided into " classroom ratio + notes + answer questions", usual score is divided into "homework + quality"; the course practice report is decomposed into "complete + format specification + achievements quality", the reply scores were divided into "random sample + group question", given the corresponding weight. Detailed evaluation index system is shown in Fig. 1.

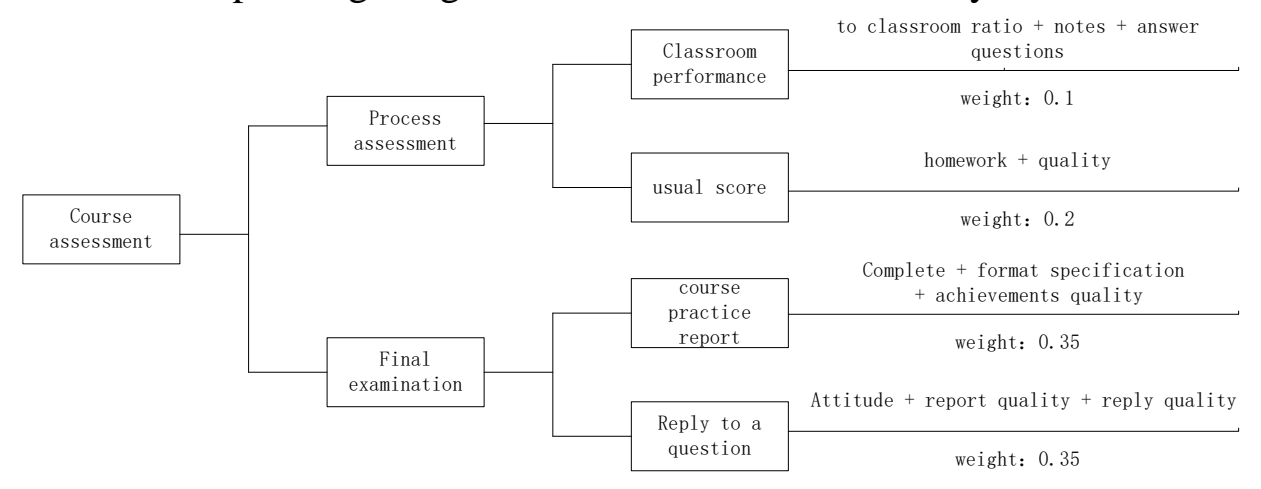

Fig. 1 Assessment evaluation index system

\subsection{Define of the criteria for judging the grade of usual performance}

Usual score are divided into two aspects of the classroom performance and the usual homework. Classroom performance accounted for $10 \%$ of the total score. 8 points are taken as the basis points, taking to classroom situation, classroom discipline, notes for the reduction of sub items and actively answering questions to add items. Usual score evaluation table are shown in Table 1. Such as Zhang 
San, he altogether absent 1 times and we deduct 1 point; his notes is in general and we deduct 1 point; he occasionally absent-minded in class and we deduct 1 point; he actively speak so we give him increased 2 points. Eventually his usual score is 7 points.

Table 1 Usual score evaluation table

\begin{tabular}{c|c|c|c|c|c|c|c}
\hline $\begin{array}{c}\text { The } \\
\text { serial } \\
\text { number }\end{array}$ & $\begin{array}{c}\text { The } \\
\text { name }\end{array}$ & $\begin{array}{c}\text { Reference } \\
\text { point }\end{array}$ & $\begin{array}{c}\text { To class } \\
\text { situation }\end{array}$ & Note situation & $\begin{array}{c}\text { Classroom } \\
\text { discipline }\end{array}$ & $\begin{array}{c}\text { Answer } \\
\text { questions }\end{array}$ & $\begin{array}{c}\text { The } \\
\text { total } \\
\text { score }\end{array}$ \\
\cline { 2 - 6 } & 8 points & $\begin{array}{c}\text { Absent } \\
\text { one time } \\
\text { deduction } \\
\text { of } 1 \\
\text { points }\end{array}$ & $\begin{array}{c}\text { According to } \\
\text { the } \\
\text { circumstances } \\
\text { of the notes, } \\
\text { as appropriate } \\
\text { deduction 1-2 } \\
\text { points }\end{array}$ & $\begin{array}{c}\text { According } \\
\text { to the } \\
\text { classroom } \\
\text { discipline, } \\
\text { as } \\
\text { appropriate } \\
\text { deduction } \\
1-2 \text { points }\end{array}$ & $\begin{array}{c}\text { Answer } \\
\text { questions, } \\
\text { actively take } \\
\text { into } \\
\text { consideration } \\
\text { to add 2 - 3 } \\
\text { points }\end{array}$ & $n$ \\
\hline 1 & $\begin{array}{c}\text { Zhang } \\
\text { San }\end{array}$ & 8 & -1 & -1 & -1 & +2 & 7 \\
\hline
\end{tabular}

Homework performance of the total score is 20\%, according to the total score of 100 percent, the performance evaluation formula is:

$$
\text { Homework score }=20 \% \times \frac{1}{n} \times \sum_{i=1}^{n} \text { homework }_{i}
$$

In the formula (1), $n$ is the total number of regular assignments, [homework] $]_{i}$ is the result of time $i$ homework.

\subsection{Reflection of the student individual contribution and the overall level of the team}

(1) Contribution and proportion coefficient

In group work, summarization often is used to score a team members decided the overall performance of the team. In order to solve this problem, the concept of contribution is introduced. Before the curriculum reform, a group leader is firstly specified; the leader assigns each member's contribution degree (total 100\%) according to the system analysis, system modeling, prediction system evaluation and system decision-making in five stages. Take the 5 persons team, for example, the individual contribution of the team members is shown in table 2.

Table 2 Team member's personal contribution evaluation

\begin{tabular}{c|c|c|c|c|c|c|c}
\hline \multirow{2}{*}{$\begin{array}{c}\text { The } \\
\text { serial } \\
\text { number }\end{array}$} & \multirow{2}{*}{$\begin{array}{c}\text { The name of the } \\
\text { stage }\end{array}$} & $\begin{array}{c}\text { Team } \\
\text { member } \\
1\end{array}$ & $\begin{array}{c}\text { Team } \\
\text { member } \\
2\end{array}$ & $\begin{array}{c}\text { Team } \\
\text { member } \\
3\end{array}$ & $\begin{array}{c}\text { Team } \\
\text { member } \\
4\end{array}$ & $\begin{array}{c}\text { Team } \\
\text { member } \\
5\end{array}$ & $\begin{array}{c}\text { The total } \\
\text { score }\end{array}$ \\
\hline 1 & system analysis & $\star$ & $\sqrt{ }$ & $\sqrt{ }$ & $\sqrt{ }$ & $\sqrt{ }$ & \\
\hline 2 & system modeling & $\sqrt{ }$ & $\star$ & $\sqrt{ }$ & $\sqrt{ }$ & $\sqrt{ }$ & \\
\hline 3 & $\begin{array}{c}\text { system } \\
\text { prediction }\end{array}$ & $\sqrt{ }$ & $\sqrt{ }$ & $\star$ & $\sqrt{ }$ & $\sqrt{ }$ & \\
\hline 4 & system valuation & $\sqrt{ }$ & $\sqrt{ }$ & $\sqrt{ }$ & $\star$ & $\sqrt{ }$ & \\
\hline 5 & system decision & $\sqrt{ }$ & $\sqrt{ }$ & $\sqrt{ }$ & $\sqrt{ }$ & $\star$ & \\
\hline & $\begin{array}{c}\text { Personal } \\
\text { contribution }\left(\mathrm{D}_{i}\right)\end{array}$ & $25 \%$ & $25 \%$ & $15 \%$ & $20 \%$ & $15 \%$ & $100 \%$ \\
\hline
\end{tabular}

Note: the order given in table is iterative, may need to be repeated many times to improve in order to complete the final. " $\star$ " responsible for this task, " $\sqrt{ }$ " said to participate in this task.

By contribution degree, the final examination results (course practice report + reply) ratio coefficient k can be calculated: 


$$
k=1+\frac{D_{i}-1}{n}
$$

As shown in Table 2, the contribution of the 2 members were 25\%, 25\%, $15 \%, 20 \%, 15 \%$, respectively, their corresponding ratio coefficient was 1.05, 1.05, 0.95, 1, 0.95 .

2) course practice report and reply

In order to reflect the fairness of the assessment, the 3-5 professional class teachers are selected for scoring in the report of the scoring process. And then the average score is calculated as a benchmark for the practice of the report. In addition to the integrity of the content of the report and the quality of the results, attention must paied to the standardization of the report format. In the total score, the content accounts for $45 \%$, the quality of the results accounts for $45 \%$, the format of the normative accounting accounts for $10 \%$. Practice report evaluation table as shown in Table 3.

Table 3 practice report evaluation form

People who scored:

\begin{tabular}{c|c|c|c|c|c}
\hline \multirow{2}{*}{ Group } & $\begin{array}{c}\text { Topic } \\
\text { of } \\
\text { practice } \\
\text { report }\end{array}$ & $\begin{array}{c}\text { Completeness and } \\
\text { relevance of content } \\
45 \%\end{array}$ & $\begin{array}{c}\text { Report content } \\
\text { quality } \\
45 \%\end{array}$ & $\begin{array}{c}\text { Format } \\
\text { specification } \\
10 \%\end{array}$ & $\begin{array}{c}\text { Group } \\
\text { score }\end{array}$ \\
\hline 1 & & & & & \\
\hline 2 & & & & & \\
\hline 3 & & & & & \\
\hline$\ldots$ & & & & & \\
\hline
\end{tabular}

All of the evaluation forms are collected for the score. The results will be aggregated to calculate the average score, as the final practice report of the group results. Practice report summary table as shown in Table 4.

Table 4 Summary of results of practice report

\begin{tabular}{c|c|c|c|c|c|c|c}
\hline \multirow{2}{*}{ Group } & \multirow{2}{*}{$\begin{array}{c}\text { Topic of } \\
\text { practice report }\end{array}$} & \begin{tabular}{c} 
Teacher \\
\cline { 3 - 6 }
\end{tabular} & $\begin{array}{c}\text { Teacher } \\
2\end{array}$ & $\begin{array}{c}\text { Teacher } \\
3\end{array}$ & $\begin{array}{c}\text { Teacher } \\
4\end{array}$ & \multirow{2}{*}{$\begin{array}{c}\text { Group } \\
\text { average }\end{array}$} \\
\hline 1 & & & & & & & \\
\hline 2 & & & & & & & \\
\hline 3 & & & & & & & \\
\hline$\ldots$ & & & & & & & \\
\hline
\end{tabular}

Taking the way of randomly selected respondent can ensure that each member of the team is carefully prepared. In order to avoid overgeneralization in the question and answer session, members of the group must be involved and contribute to each team's reply. 3-5 professional class teacher and the group representatives usually be chosen to score. The respondent evaluation table as shown in Table 5. 
Table 5 Reply evaluation form

People who scored:

\begin{tabular}{l|l|c|c|c|c|c|c}
\hline \multirow{2}{*}{ Group } & \multirow{2}{*}{$\begin{array}{c}\text { Topic of } \\
\text { practice } \\
\text { report }\end{array}$} & $\begin{array}{c}\text { Manners, } \\
\text { temperament } \\
5 \%\end{array}$ & $\begin{array}{c}\text { Language } \\
\text { expression } \\
\text { ability and } \\
\text { organization } \\
\text { ability } \\
5 \%\end{array}$ & $\begin{array}{c}\text { The } \\
\text { integrity of } \\
\text { the report } \\
\text { contents } \\
35 \%\end{array}$ & $\begin{array}{c}\text { The } \\
\text { accuracy of } \\
\text { the contents } \\
\text { of the report } \\
35 \%\end{array}$ & $\begin{array}{c}\text { Accura } \\
\text { cy of } \\
\text { reply } \\
20 \%\end{array}$ & $\begin{array}{c}\text { Team } \\
\text { Score }\end{array}$ \\
\hline 1 & & & & & & & \\
\hline 3 & & & & & & & \\
\hline$\ldots$ & & & & & & & \\
\hline
\end{tabular}

The evaluation form of the score also need to be collected, whose results will be aggregated to calculate the average score as the respondent group score. The reply summary table as shown in Table 6.

Table 6 reply summary table

\begin{tabular}{|c|c|c|c|c|c|c|c|}
\hline \multirow[b]{2}{*}{ Group } & \multirow[b]{2}{*}{$\begin{array}{c}\text { Topic of } \\
\text { practice report }\end{array}$} & \multicolumn{5}{|c|}{ People who scored } & \multirow[b]{2}{*}{$\begin{array}{l}\text { Team } \\
\text { Score }\end{array}$} \\
\hline & & $\begin{array}{c}\text { People } \\
\text { who } \\
\text { scored } 1\end{array}$ & $\begin{array}{c}\text { People } \\
\text { who } \\
\text { scored } 2\end{array}$ & $\begin{array}{c}\text { People } \\
\text { who } \\
\text { scored } 3\end{array}$ & $\begin{array}{c}\text { People } \\
\text { who } \\
\text { scored } 4\end{array}$ & $\cdots$ & \\
\hline 1 & & & & & & & \\
\hline 2 & & & & & & & \\
\hline 3 & & & & & & & \\
\hline ․ & & & & & & & \\
\hline
\end{tabular}

Thus, a final lesson each student assessment results can be drawed as follows:

Final examination results $=35 \% \times k \times($ Group report average + Average score of group reply) (3)

Whether it is a practice report or the respondent's results, it is just a result of the group. To calculate the score of a person, the proportion coefficient of the team members $K$ need to be multiplied. The contribution of the concept can be separate team member performance, so in larger extent solve overgeneralization, unreasonable distribution of the situation.

\section{Analysis on the reform effect of the examination mode of professional practice course}

The examination mode to combine process examination, final examination, writing report and answering question has already achieved some achievements in the course of teaching ${ }^{[5,6]}$. Through in front of the refined evaluation index system, clear usual time performance criteria, reflecting the overall level of team and students' individual contribution and etc. Several practices, the practical problems are greatly solved, encountered in the professional practice course assessment and recognized by the students and teachers.

(1) The enthusiasm, initiative and practical ability of the students are generally improved. The examination method, which runs through the whole course of the examination, not only pays attention to the performance of the ordinary, but also focuses on the final exam. Now, students are generally paying more attention to the usual performance and change the attitude there is little attention paid to the professional practice of the course. Students change from passive learning into active learning and the quality of learning is improved ${ }^{[7,8]}$.

(2) The contribution has been introduced, so as to achieve the professional practice of the assessment of the fairness of the course. The team leader according to the usual performance determines the contribution of team members, and then calculates the proportion coefficient, so that each group has a degree of achievement, which greatly mobilizes the enthusiasm of the students to 
practice. Professional practice courses is different from the general basic courses, the evaluation can not only by virtue of a piece of paper to judge, the establishment of a complete system of the evaluation standard of the assessment model can solve problem of assessment is not fair.

(3) This kind of exploration promotes the reform of teaching method and improves the teaching quality. The examination method makes teachers to have more strong sense of responsibility, to promote them to learn and acquire more professional knowledge and skills, to prepare lessons more carefully, to pay more attention to the normative explanation, in the process of practice more strict demands on students ${ }^{[9,10]}$.

\section{Conclusion}

The reform of the assessment mode is carried out, not only makes the assessment more scientific and fair, but also makes the assessment more feasible and workable. Through this type of assessment, the students' comprehensive ability can be effectively tested, the more attention of students paid to whole teaching process and the ability of students is fully upgrade. The model has a positive reference to other types of examination mode in the course of reform.

\section{References}

[1]. Zhi-fang Zhang, Research and Exploration of Experimental Teaching Examination Methods, Shandong Textile Economy, 2008(3): 118-119.

[2]. Zeng-qiang Mi, Research and Practice on the reform of examination mode in Colleges and Universities, China Electric Power Education, 2002(3): 93- 97.

[3]. Tie-guang Wang, Xiang-lin Hou, Reform the examination mode to adapt to the development of quality education, Education research in Liaoning, 2000 (7): 23- 24.

[4]. Ya-ping Cai, Problem solving based on real situation of the teaching design, Electrochemical education research, 2011(6): 17-19.

[5]. Hong-qi Yu, QingZhongGong, Application and practice of cultivating engineering students' consciousness of engineering innovation, journal of Beijing city university, 2011(4): 26-27.

[6]. Ji-ying Huang, Practice teaching and its revelation of the foreign university, Tsinghua university education research, 2006 (4):29-32

[7]. Ying-yan Zhang, Theory of practice teaching goal, education and research, 2006 (5): 51-54.

[8]. Ying-yan Zhang, Concerning the theoretical basis of the practice teaching, education science, 2006 (8): 63-68

[9]. Yan Zhang, Optimize the practice teaching research, education and research, 2008 (4): 83-86.

[10]. Ming-gang Zhao, American colleges and universities teaching practice mode, education review, 2011 (1): 56-58 